\title{
Revisão taxonômica do gênero Periandra Mart. ex Benth. (Leguminosae, Papilionoideae, Phaseoleae) ${ }^{1}$
}

\author{
LIGIA SILVEIRA FUNCH ${ }^{2}$ e GRAZIELA MACIEL BARROSO ${ }^{3}$
}

(recebido em 21/11/97; aceito em 08/03/99)

\begin{abstract}
Taxonomic revision of the genus Periandra Mart. ex Benth. (Leguminosae, Papilionoideae, Phaseoleae)). Periandra Mart. ex Benth. is an essentially Brazilian genus comprising six species native to "cerrado" and "campo" vegetation. In this revision, the genus is separated into two subgenera: Periandra subg. Periandra and Periandra subg. Coccinea Funch \& Barroso, based on macromorphological characteristics, approached in this paper, and palinological characteristics published earlier. None of the varieties previously proposed for $P$. mediterranea were accepted. One species, $P$. berteriana, does not seem to fit into the genus.
\end{abstract}

RESUMO - (Revisão taxonômica do gênero Periandra Mart. ex Benth. (Leguminosae, Papilionoideae, Phaseoleae)). O gênero Periandra Mart. ex Benth. é constituído por seis espécies, essencialmente brasileiras, distribuídas principalmente em campos e cerrados. Nesta revisão o gênero foi dividido em dois subgêneros: Periandra subg. Periandra e Periandra subg. Coccinea Funch \& Barroso. A proposta destes subgêneros foi baseada em caracteres macromorfológicos, abordados neste trabalho, e polínicos, tratados anteriormente. Nenhuma das variedades anteriormente descritas para P. mediterranea foi aceita. Uma espécie, P. berteriana, foi considerada duvidosa.

Key words - Periandra, revision, Leguminosae, taxonomy

\section{Introdução}

O gênero Periandra foi estabelecido por Bentham (1837), validando manuscrito de Martius. Nesse trabalho, 10 espécies foram descritas e o gênero foi incluído na subtribo Clitoriinae (como Clitorieae), diferenciado de Clitoria pela forma do cálice e de Centrosema pelo vexilo não calcarado. Esta afinidade genérica é, ainda hoje, reconhecida, sendo Periandra integrante da tribo Phaseoleae subtribo Clitoriinae juntamente com Clitoria, Centrosema, Clitoriopsis (Lackey 1981) e Barbieria (Fantz 1996).

Das 10 espécies originalmente descritas, três $(P$. angulata, P. mucronata e $P$. racemosa) foram sinonimizadas por Bentham (1859) com P. dulcis. Nesse trabalho não foi feita qualquer menção a $P$. angustifolia, espécie afim a $P$. dulcis. Desta forma, o gênero passou a ser constituído por seis espécies: P. acutifolia, P. coccinea, P. dulcis, P. densiflora, P. heterophylla, do Brasil, e P. berteriana, da Ilha de São Domingos - Hispaniola (Bentham 1865).

1. Parte da dissertação de mestrado de L.S. Funch, no Departamento de Botânica, Universidade Estadual de Campinas, SP, Brasil.

2. Departamento de Ciências Biológicas, Universidade Estadual de Feira de Santana, BR 116, Km 3, Campus Universitário, 44031-460 Feira de Santana, BA, Brasil.

3. Jardim Botânico do Rio de Janeiro, R. Pacheco Leão 915, 22460-030 Rio de Janeiro, RJ, Brasil.
Além destas, algumas espécies foram descritas por diferentes autores, como P. parviflora (Micheli 1894), que foi posteriormente sinonimizada com Galactia discolor J.D. Smith (Standley \& Steyermark 1946), P. gracilis (Irwin \& Arroyo 1972) e P. pujalu (Emmerich \& Senna 1980).

Mattos \& Oliveira (1973) consideraram seis espécies e descreveram as variedades $P$. mediterranea var. mycrophylla, P. mediterranea var. linearifolia e P. mediterranea var. mucronata. Porém esse estudo pouco acrescentou às descrições originais de Bentham (1837), não apresentou pranchas ilustrativas das espécies e variedades e forneceu uma chave analítica de difícil aplicação.

Assim, o gênero Periandra inclui 13 espécies e três variedades, com distribuição neotropical, encontradas especialmente em campos e cerrados.

A morfologia polínica de Periandra (Funch \& Watanabe 1994) auxiliou a definir a abordagem taxonômica apresentada no presente estudo, pois foram reconhecidas descontinuidades no tamanho e forma dos grãos de pólen, tipo de abertura e ornamentação da exina entre dois grupos infragenéricos.

O presente estudo procurou avaliar a taxonomia do gênero e fornecer dados morfológicos atuais que contribuíssem para uma delimitação mais precisa das espécies. A distribuição geográfica dos táxons considerados foi atualizada. 


\section{Material e métodos}

Este trabalho foi baseado em análise morfológica comparativa de espécimes de herbários, nacionais e estrangeiros. Tendo em vista a grande quantidade de material examinado, optou-se pela citação de coleções de referência, representativas da distribuição geográfica de cada espécie. As siglas dos herbários estão de acordo com Holmgren et al. (1990) e a citação completa do material examinado encontra-se em Silveira (1991).

Folíolos de todas as espécies foram diafanizados pelo método de Foster (1950), para exame do padrão de venação e de tricomas. A nomenclatura para forma e pilosidade das estruturas foi baseada em Radford et al. (1974) e Rizzini (1977). Para nervação foliar utilizou-se Hickey (1973).

Para a descrição das plântulas foram utilizadas sementes provenientes do material seguinte: $P$. coccinea - Coradin 4376, 6975, 7275 (CEN); P. densiflora - Coradin 7300 (CEN); P. pujalu Coradin 7279 (CEN) e P. mediterranea - Silveira s.n. (UEC 24192). As sementes foram superficialmente escarificadas, colocadas para germinar em placas de Petri com papel de filtro úmido e plantadas em vermiculita. Após análise, as plântulas foram herborizadas e depositadas no herbário UEC. A morfologia das plântulas de Periandra foi descrita segundo Duke \& Polhill (1981), enfocando prioritariamente os caracteres considerados de maior importância para a taxonomia da tribo Phaseoleae (Baudet 1974).

Populações de algumas espécies foram observadas no campo: P. mediterranea nas serras do Cipó, Caraça (Minas Gerais) e Sincorá (Bahia); P. pujalu e $P$. coccinea na Serra do Sincorá.

\section{Resultados e Discussão}

Hábito - As espécies de Periandra são geralmente arbustos ou subarbustos, raramente ervas (P. heterophylla), escandentes ou eretos, com pouca ramificação. A variação intra-específica é comum, estando relacionada aos diversos ambientes que as espécies ocupam. Espécies arbustivas, subarbustivas ou herbáceas, predominantemente eretas (P. mediterranea, $P$. gracilis e $P$. heterophylla) apresentam um sistema subterrâneo bem desenvolvido, semelhante a um xilopódio; as espécies arbustivas escandentes $(P$. coccinea, $P$. densiflora e $P$. pujalu) são geralmente estoloníferas.

Indumento - Não há variação morfológica considerável no indumento das espécies de Periandra. Dois tipos de tricomas, simples e unisseriados, foram evidenciados: Tipo I, constituído de duas células basais pequenas e uma célula distal reta, com ápice agudo, extremamente variável em tamanho; Tipo II, tricomas uncinados, constituídos de duas células basais e uma célula distal curva. Aspectos de densidade e coloração são significativos na taxonomia do grupo, variando de esparso a densamente pubérulo, ou pubérulo e seríceo, ocasionalmente velutino ( $P$. coccinea e $P$. heterophylla), canescente ou canescente-ocráceo; apenas em $P$. gracilis, a ausência de tricomas é predominante. A face abaxial dos folíolos é pruinosa nos espaços entre os retículos. Na flor, o indumento varia de pubérulo a tomentoso (cálice), pubérulo e seríceo (face dorsal do vexilo), seríceo (região dorsal do calo e unguícula do vexilo), pubérulo e com tricomas escamiformes (face ventral do vexilo e das alas), pubérulo (face dorsal das alas e carena) e seríceo (ovário); tricomas escamiformes, triangulares de base larga e curtos, são encontrados principalmente no ápice das pétalas e parecem relacionados à escultura das alas (Stirton 1981).

Folha - As folhas são sempre alternas, pinadotrifolioladas ou, ocasionalmente, unifolioladas na base (P. heterophylla); pecíolos de comprimento variável, apenas $P$. heterophylla e $P$. mediterranea possuem folhas subsésseis. A forma dos folíolos é extremamente variável, de ovados a lanceolados (ovadolanceolados, ovado-oblongos, elípticos, oblongos), às vezes obovados, com base arredondada a aguda, às vezes subcordada, e ápice agudo a arredondado, às vezes retuso, sempre mucronado; em geral a textura é coriácea ou cartácea, raramente rugosa $(P$. coccinea e $P$. heterophylla). A venação é camptódromo-broquidódroma, com seis a 18 nervuras secundárias; estípulas e estipelas estão sempre presentes, ovadas ou ovado-lanceoladas e setáceo-lineares, respectivamente.

Inflorescência - Em P. mediterranea (figura 1), verifica-se uma inflorescência aparentemente indeterminada, pois há numerosas brácteas no ápice do eixo principal contínuo. Os ramos laterais são precedidos por brácteas de $1^{\underline{a}}$ ordem, seguidas de ramos extremamente curtos. Os ramos suportam flores

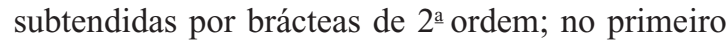
par, as flores são geralmente opostas e as apicais são opostas ou isoladas. Ramos curtos em zigue-zague são bem evidentes na espécie, semelhantes a cincínios. Por isso, sugere-se que em $P$. mediterranea, as inflorescências sejam consideradas politélicas com ramos laterais cimóides. Observando as inflorescências de $P$. gracilis (figuras 2 e 3 ) e $P$. pujalu (figuras 4 e 5), percebe-se um padrão semelhante nestas espécies, reconhecido pela forma em zigue-zague do eixo principal e ramos laterais curtos, formando pequenos cincínios. Nesse caso, é duvidoso afirmar se o eixo principal tem crescimento indeterminado. Os ramos laterais são extremamente contraídos (figuras 3 e 5), apresentando uma aparência genuflexa 
bem marcante; quando carregam três flores, inicialmente abre-se a flor basal, seguida respectivamente da segunda e terceira, seqüência descrita para os cincínios (Radford et al. 1974, Foster \& Gifford 1979). As inflorescências de $P$. gracilis e $P$. pujalu parecem tipos bastante reduzidos daquele encontrado em $P$. mediterranea, principalmente no que se refere aos ramos laterais, conferindo-lhes um aspecto mais laxo. A inflorescência de $P$. densiflora (figura 8 ) revela notável redução do eixo principal, cuja enorme quantidade de brácteas ainda presentes parece testemunhar esse processo. Os ramos laterais seguem o padrão evidenciado nas espécies anteriores. Por outro lado, as inflorescências observadas em $P$. coccinea e $P$. heterophylla (figura 6) apresentam um tipo no qual especialmente os ramos laterais foram reduzidos (figura 7). Nestas espécies, o eixo principal parece de crescimento determinado, bem como os ramos laterais. Estes geralmente suportam duas flores, antecedidas por brácteas de $2^{\mathrm{a}}$ ordem; ocasionalmente, a flor central tem desenvolvimento completo. Interpretou-se os resultados tomando como tipo básico de inflorescência no gênero Periandra, aquele encontrado em $P$. mediterranea. Portanto, estes dados parecem corroborar a idéia de que cimeiras possam ter sido derivadas na evolução das Leguminosae, como proposto por Tucker (1987). Em Periandra, compreende-se os ramos laterais como determinados por se considerar que: a) eles são unidades dicasiais modificadas, onde se pode observar abortamento principalmente em flores laterais; b) a bráctea que subtende a flor mais apical pode ser uma bráctea de $2^{a}$ ordem remanescente da unidade dicasial, permitindo a interpretação desta flor como terminal; c) em pseudoracemos, segundo Tucker (1987), a flor mediana tem desenvolvimento sincrônico ou mais adiantado que as laterais da tríade, fato não verificado nas espécies estudadas como se observa na figura 3 , que mostra apenas o desenvolvimento das flores laterais.

Flor - As flores das espécies de Periandra são tipicamente papilionáceas, zigomorfas, ressupinadas na pré-antese, pediceladas, com bractéolas (2) pareadas e opostas, inseridas na base do cálice, ovadas a lanceoladas. O cálice apresenta pouca variação entre as espécies, campanulado, bilabiado, o lábio carenal com três lacínias triangulares a subtriangulares, a mediana mais longa que as demais e o lábio vexilar com duas lacínias subconadas, bidentado. A corola varia nas cores azul-violácea e vermelha; o vexilo é uniformemente suborbiculado, com base não auriculada, unguícula externamente gibosa e internamente cuculada, calo basal evidente e ápice emarginado; as alas variam de obliquamente obovadas (P. mediterranea, $P$. gracilis, $P$. densiflora e $P$. pujalu) a estreitas, oblongas, sigmóides ( $P$. coccinea e $P$. heterophylla); as pétalas da carena são amplas, obliquamente ovadas; em P. coccinea e P. heterophylla, as flores são relativamente maiores.

Fruto e semente - $\mathrm{O}$ fruto é um legume linear, reto ou levemente curvo, achatado, com ápice agudo ou rostrado, base aguda, castanho ou castanho-avermelhado; o cálice é persistente; deiscência elástica, através de margens marcadamente engrossadas. As sementes em geral são 11-20 por fruto, com um funículo curto; a forma pode variar, mesmo dentro de uma espécie, de oblonga, reniforme a suborbiculada; a testa é sempre coriácea, castanha, castanho-avermelhada ou cinza, com manchas negras ou lisa; às vezes foi possível identificar um tégmen membranáceo, hialino ou amarelado, o hilo é pequeno, oblongo ou suborbicular, lateralmente mediano em relação ao eixo da semente adjacentes ao hilo encontram-se a micrópila e o estrofíolo; o embrião é axial, tipicamente papilionáceo, ocupando toda a semente; os cotilédones são plano-convexos, oblongos ou reniformes, crassos, com base auriculada, o eixo hipocótilo-radícula infletido, adpresso ao corpo dos cotilédones, sem plúmula desenvolvida.

Plântula - Características de plântulas foram investigadas para quatro espécies, ficando evidenciados dois grupos infragenéricos. Um grupo apresenta plântulas fanerógeas, como observadas em $P$. mediterranea (figura 9), P. pujalu (figura 10) e P. densiflora (figura 11), no qual os cotilédones são sésseis, oblongos, crassos, glabros, o epicótilo varia de 3-7 cm compr., pubérulo, os eófilos são sempre opostos, com estípulas (2) inteiras, triangulares, estipelas (2) setáceo-lineares, peciolados, com forma variável, de elípticos ou oblongos (P. mediterranea) a largoovados, base obtusa (P. mediterranea) ou subcordada, ápice obtuso, mucronado, membranáceos, sendo o primeiro metáfilo unifoliolado, lanceolado ( $P$. mediterranea), ou trifoliolado, seguido de metáfilos trifoliolados. O outro grupo exibe plântulas faneroepígeas, como em $P$. coccinea (figura 12), em que o hipocótilo apresenta 1,5-2 cm compr., pubérulo, os cotilédones são subsésseis, oblongos, crassos, pubé- 

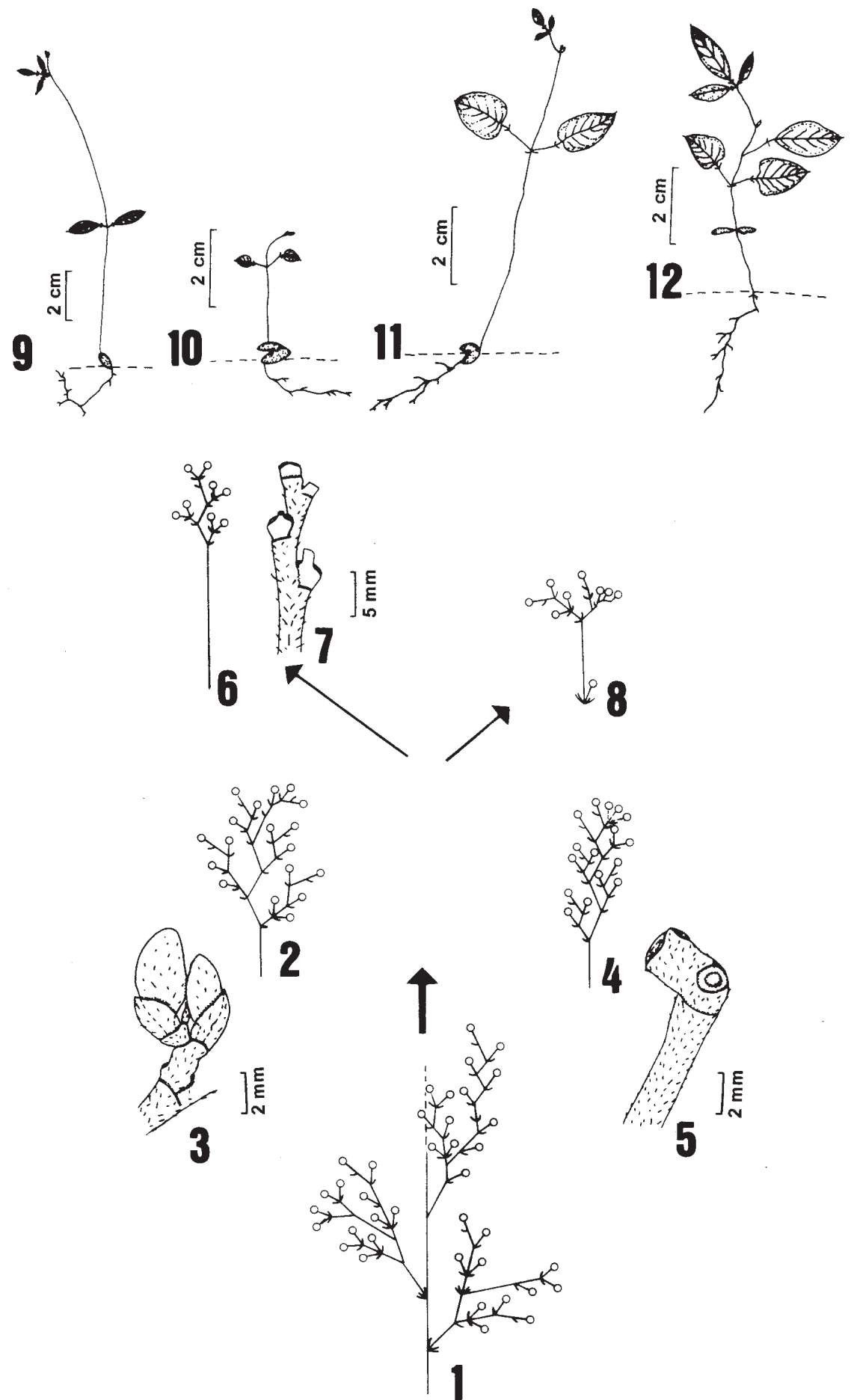

Figuras 1-12. Provável linha evolutiva dos tipos de inflorescências encontrados em Periandra. 1. P. mediterranea; 2. P. gracilis; 3. P. gracilis, detalhe de um ramo lateral (Heringer 4227); 4. P. pujalu; 5. P. pujalu, detalhe de um ramo lateral (Valls 12561); 6. P. coccinea e P. heterophylla; 7. P. coccinea, detalhe do ápice (Shepherd 7510); 8. P. densiflora. Figuras 9-12. Aspecto das plântulas encontradas em Periandra. 9. P. mediterranea; 10. P. pujalu; 11. P. densiflora; 12. P. coccinea. 
rulos, o epicótilo possui 1,5-2 cm compr., pubérulo, os eófilos são opostos, com estípulas (2) bífidas, estipelas (2), setáceo-lineares, peciolados, largo-ovados, com base reniforme, ápice obtuso, mucronado, membranáceos, sendo o primeiro metáfilo trifoliolado, ocasionalmente unifoliolado.

Periandra Mart. ex Benth., Comm. Leg. Gen. p.56. 1837.

Espécie-tipo (aqui designada): Periandra mediterranea (Vell.) Taub.

Glycinopsis Kuntze, Rev. Gen. Plant. 1:190. 1891.

Arbustos, subarbustos ou ervas eretas ou ascendentes, ocasionalmente prostrados, muitas vezes com sistema subterrâneo semelhante a um xilopódio, ou trepadeiras volúveis, geralmente estoloníferas. Indumento esparso a densamente pubérulo e seríceo, ocasionalmente subvelutino, canescente ou canescenteocráceo, recobrindo as partes vegetativas. Folhas 3folioladas, ocasionalmente 1-folioladas na base dos ramos; estípulas 2, ovadas ou ovado-lanceoladas, estriadas; pecíolos estriados, às vezes sulcados; ráquis foliar sulcada, estriada; estipelas setáceo-lineares, estriadas; folíolos subsésseis ou peciolulados, lanceolados a ovados; camptódromo-broquidódromos. Inflorescência racemosa ou cimosa, axilar ou terminal, pauciflora ou multiflora, laxa ou congesta, subséssil ou longamente pedunculada; brácteas ovadas a lanceoladas, agudas ou acuminadas, estriadas. Flores papilionáceas, ressupinadas, pediceladas; bractéolas 2, ovadas a lanceoladas, ou suborbiculadas, côncavas, agudas ou acuminadas, estriadas; cálice campanulado, bilabiado, lábio carenal com 3 lacínias, a mediana mais longa que as demais, o lábio vexilar 2dentado; corola azul-violácea ou vermelha; vexilo suborbiculado, base não auriculada, calo conspícuo, unguícula externamente gibosa e internamente cuculada, ápice emarginado, face dorsal pubérula e serícea, margens ciliadas, face ventral levemente pubérula e com tricomas escamiformes; alas obliquamente obovadas ou oblongas, estreitas, sigmóides, base auriculada ou não, presas à porção mediana da carena, ápice livre, assimétrico ou obtuso, face dorsal levemente pubérula, face ventral com tricomas escamiformes; pétalas da carena amplas, obliquamente ovadas, não auriculadas, unguícula curta, face dorsal levemente pubérula, margens ciliadas; estames 10, o vexilar livre, com alternância de filetes longos e curtos; anteras orbiculadas, uniformes, versáteis, rimo- sas; ovário linear, levemente curvo, achatado, subestipitado, piloso, canescente, disco nectarífero basal denteado; estilete curvo, achatado ou ligeiramente anguloso, levemente piloso na metade inferior, raro inteiramente glabro; estigma terminal, cuneiforme, oblíquo em vista lateral, glabro ou com tricomas curtos, canescentes. Legume linear, reto ou levemente curvo, subestipitado; sementes 11-20, oblongas, reniformes ou suborbiculadas, exalbuminadas; testa coriácea, tégmen membranáceo, hialino, amarelado; hilo pequeno ca. $2 \mathrm{~mm}$, oblongo ou suborbicular, lateral, mediano; micrópila e estrofíolo adjacentes ao hilo; embrião axial, cotilédones plano-convexos, oblongos ou reniformes, crassos, base auriculada, eixo hipocótilo-radícula infletido, adpresso ao corpo dos cotilédones e plúmula não desenvolvida.

Há em Periandra dois grupos com características diferenciadas na coloração da corola, forma das alas, comprimento do pedúnculo da inflorescência, densidade e coloração do indumento das partes vegetativas e tipo de plântulas. Dados da morfologia polínica, como tamanho e forma dos grãos, tipo de abertura e ornamentação da exina (Funch \& Watanabe 1994) e observações preliminares de biologia floral corroboram a delimitação destes grupos (Silveira 1991). Neste trabalho, tais grupos estão sendo tratados como Periandra subg. Periandra e Periandra subg. Coccinea.

Chave para identificação dos subgêneros e espécies de Periandra

1. Corola azul-violácea; alas obliquamente obovadas, com ápice assimétrico; inflorescência racemosa terminal ou axilar (Periandra subg. Periandra)

2. Inflorescência pauciflora, até 8 flores, laxa, pedúnculos alcançando até $10 \mathrm{~cm}$ compr., ocasionalmente subsésseis

3. Plantas com hábito arbustivo ereto, glabras, raramente pubérulas .............. 2. P. gracilis

3. Plantas trepadeiras, volúveis, pubescentes

4. Lacínia mediana do lábio inferior do cálice triangular, 3-5 $\mathrm{mm}$ compr.

3. P. pujalu

4. Lacínia mediana do lábio inferior do cálice lanceolada, 9-14 mm compr. 4. P. densiflora

2. Inflorescência densiflora, com mais de 20 flores, congesta, pedúnculos até $0,2 \mathrm{~cm}$ compr. 1. P. mediterranea 
1. Corola vermelha; alas estreitas, oblongas ou sigmóides, com ápice obtuso; inflorescência cimosa, axilar (Periandra subg. Coccinea)

5. Folhas pecioladas, pecíolo $10-65 \mathrm{~mm}$ compr.; trepadeiras volúveis, ocasionalmente arbustos flexuosos 5. P. coccinea

5. Folhas subsésseis, pecíolo até $3 \mathrm{~mm}$ compr.; ervas ou subarbustos eretos ou ascendentes 6. P. heterophylla

\section{Periandra subg. Periandra}

Espécie-tipo: Periandra mediterranea (Vell.) Taub.

Arbustos eretos ou escandentes, até 3,5 m alt.; indumento esparso a densamente pubérulo ou pubérulo e seríceo, ocasionalmente subvelutino, canescente, recobrindo as partes vegetativas, ou às vezes ausente; inflorescências terminais ou axilares, com pedúnculo variando de subséssil até $10 \mathrm{~cm}$ compr.; corola azul-violácea; alas obliquamente obovadas, com ápice assimétrico; grãos de pólen de tamanho médio, prolato-esferoidais, 3-colporados ou, raramente, heterocolpados, reticulados; plântulas fanerógeas.

Periandra mediterranea (Vell.) Taub., in Engl. \& Prantl, Nat. Pflanzenfam. 3(3):359. 1894.

Figuras 13-26.

Glycyrrhiza mediterranea Vell., Fl. Flum. p.317. 1829; Icon. 7:t.145. 1831. Tipo: Vellozo. Fl. Flum. Icon. 7:t.145. 1831.

P. dulcis Mart. ex Benth., Comm. Leg. Gen. p.57. 1837, nom. illeg.

P. racemosa Benth., Comm. Leg. Gen. p.57. 1837. Tipo: Brasil, Goiás, Serra Dourada, Pohl s.n. (holótipo K!; fotografias A!, NY!, F!, UEC!).

P. angulata Benth., Comm. Leg. Gen. p.57. 1837. Tipo: Brasil, São Paulo, Pohl s.n. (holótipo K!; fotografia A!).

P. mucronata Benth., Comm. Leg. Gen. p.57. 1837. Tipo: Brasil, Minas Gerais, Martius s.n. (lectótipo, aqui designado K!); Bahia, Martius s.n. (paralectótipo K!).

P. angustifolia Benth., Comm. Leg. Gen. p.57. 1837. Tipo: Brasil, Minas Gerais, Martius s.n. (não localizado).

Glycinopsis mediterranea (Vell.) Kuntze, Rev. Gen. Plant. 1:190. 1891.

P. mediterranea var. linearifoliolata N. Mattos \& F. Oliveira, Loefgrenia 59:7. 1973. Tipo: Brasil, Mi- nas Gerais, Diamantina, XI-1937 (fl.), Mello Barreto s.n. (holótipo SP!), syn. nov.

P. mediterranea var. mucronata (Benth.) Burkart ex N. Mattos \& F. Oliveira, Loefgrenia 59:7. 1973. Tipo: sub $P$. mucronata cit., syn. nov.

P. mediterranea var. microphylla N. Mattos \& F. Oliveira, Loefgrenia 59:7. 1973. Tipo: Brasil, Pará, Prainha, campo, 11/5/1903 (fl.), A. Ducke 3619 (holótipo US; isótipos BM!, G!, MG!), syn. nov.

Arbustos 1-2(-3,5)m alt., eretos, raramente prostrados, subramificados; sistema subterrâneo bem desenvolvido. Partes vegetativas esparso a densamente pubérulas ou pubérulas e seríceas. Folhas com estípulas 1,8-5 x 0,5-2,5 mm, ovadas ou ovado-lanceoladas; pecíolos 0,5-5 mm compr.; ráquis foliar 1$14 \mathrm{~mm}$ compr.; estipelas 1-5 mm compr.; peciólulos 0,5-3 mm compr.; folíolos 2,7-12 x 0,4-4,9 cm, lanceolados, obovados, ovados, ovado-oblongos ou linear-lanceolados, base aguda a arredondada, ápice agudo a arredondado, às vezes retuso, margens ocasionalmente revolutas, coriáceos; face abaxial com nervuras pubérulas e seríceas, pruinosa nos espaços formados pelos retículos, face adaxial glabra. Inflorescência racemosa, com ramos laterais cimóides, terminal ou axilar, densiflora, congesta, subséssil, pedúnculo até $2 \mathrm{~mm}$ compr.; brácteas 2-5 x 1-2 mm, ovadas ou ovado-lanceoladas, côncavas. Flores 2,1$4 \mathrm{~cm}$ compr.; pedicelos $2-12 \mathrm{~mm}$ compr.; bractéolas 2-7,5 x 1,5-2,5 mm, ovadas ou ovado-lanceoladas, agudas; tubo calicino 2,5-5 mm compr.; lacínias do lábio carenal triangulares, 2,5-5 mm compr.; vexilo 1,8-3,5 x 1,6-3,6 cm; alas 1,7-3 cm compr.; peças da carena 1,6-2,9 cm compr., obliquamente ovadas ou oblongas, pubérulas e com tricomas escamiformes; estames 1,8-2,8 cm compr.; ovário 1-1,5 cm compr.; estilete 1,2-1,8 cm compr., ligeiramente piloso até abaixo da metade. Legume 6-12 cm compr., castanho-avermelhado; sementes 9-13 por fruto, 5-7 x 4,5$5 \mathrm{~mm}$, suborbiculadas ou oblongas; testa castanhoavermelhada, lisa; hilo suborbicular.

Comentários: Taubert (1894) formou uma nova combinação para o gênero Periandra - P. mediterranea - legitimando a opinião de Bentham (1837) ao posicionar $P$. dulcis na sinonímia de Glycyrrhiza mediterranea Vell. P. dulcis é nome ilegítimo, nomenclaturalmente supérfluo, conforme Art. 52.1 (Greuter et al. 1994), pois o táxon para o qual foi aplicado, como circunscrito por Bentham (1837), incluía o tipo de Glycyrrhiza mediterranea. Bentham (1837) 


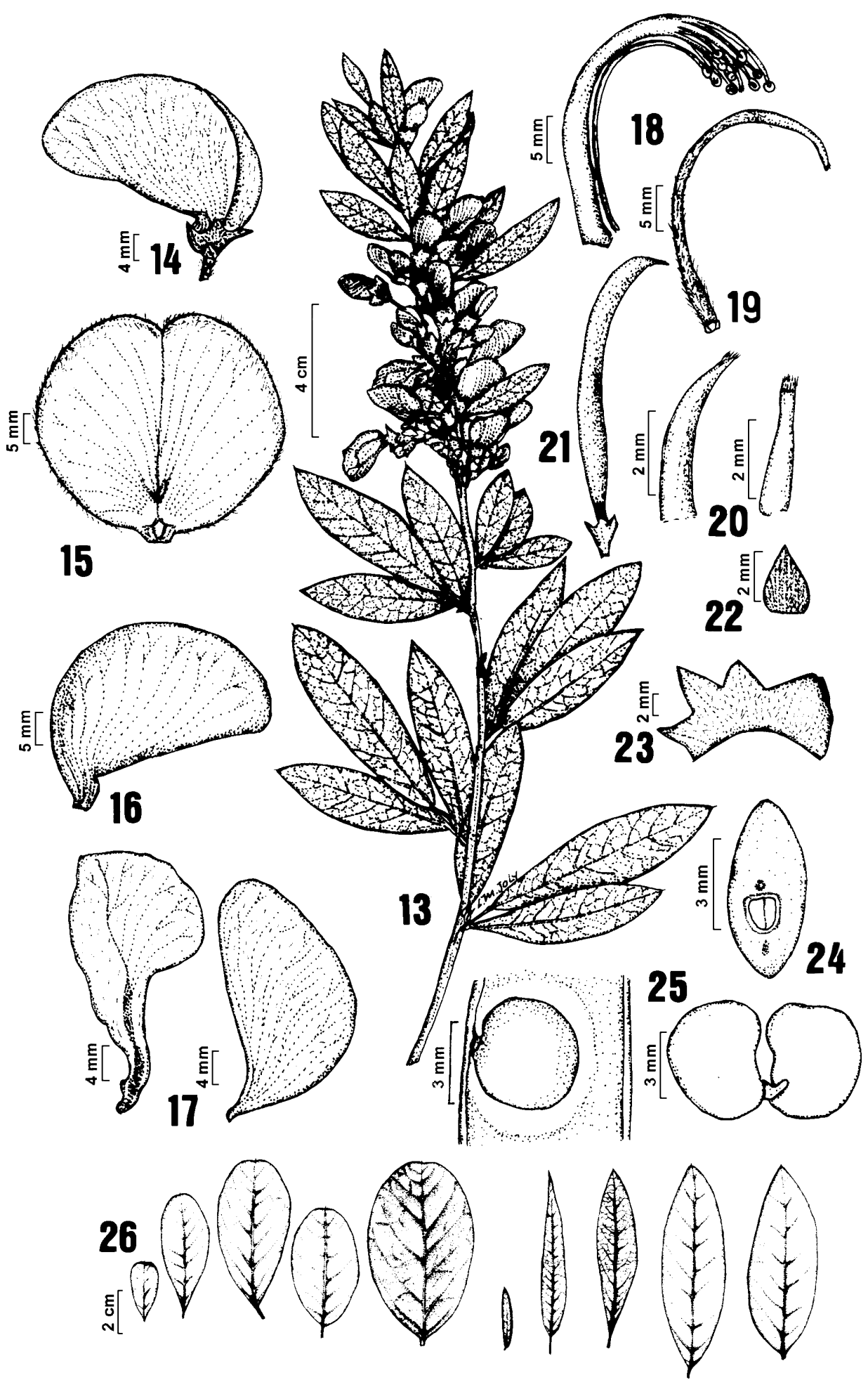

Figuras 13-26. P. mediterranea (Vell.) Taub. (Silva 2997). 13. Aspecto do ramo; 14. Flor; 15. vexilo, face ventral; 16. Vexilo, vista lateral; 17. Ala e carena; 18. Androceu; 19. Gineceu; 20. ápice do estilete e estigma, vistas lateral e frontal; 21. Fruto; 22 . Bractéola; 23. Cálice; 24. Semente, vista lateral (Ducke 11388); 25. Semente no fruto e embrião (Ducke 11388); 26. Variação morfológica dos folíolos (Ducke s.n. (RB11937); Jesus 495; Barreto 9431; Silva 2997; Irwin 19866; Irwin 19295; Silveira s.n. (UEC 24194); Irwin 34024; Rizzo 4158; Silva 1769). 
estabeleceu cinco espécies no gênero: $P$. dulcis, P. mucronata, P. angulata, P. racemosa e P. angustifolia, separadas basicamente por variações na forma dos folíolos. Posteriormente, Bentham (1859) sinonimizou P. mucronata, $P$. angulata e $P$. racemosa com $P$. dulcis (= P. mediterranea), ampliando o limite desta espécie. Mattos \& Oliveira (1973) apresentaram três variedades para $P$. mediterranea, além da típica, baseandose, novamente, em variações de forma e tamanho dos folíolos. Além disso, os autores sinonimizaram $P$. angustifolia com $P$. mediterranea, reconhecendo a afinidade existente entre estas espécies. O material examinado neste trabalho forneceu evidência de um gradiente de variação na forma dos folíolos (figura 26) de $P$. mediterranea, que muitas vezes pode ser observado em um único exemplar. Portanto, não foram aceitas variedades para a espécie. P. mediterranea exibe acentuado polimorfismo, tanto nos folíolos quanto no hábito. Observaram-se indivíduos crescendo nas restingas de Ilhéus (Bahia), como arbustos difusos com ramos decumbentes ou prostrados, e na Serra do Caraça (Minas Gerais), como arbustos eretos com até 3,5 $\mathrm{m}$ de altura. P. mediterranea é identificada por suas inflorescências densifloras, congestas, com pedúnculo bastante curto (até $2 \mathrm{~mm}$ compr.), o que a diferencia de $P$. gracilis e P. pujalu, espécies mais intimamente relacionadas. É a espécie com distribuição mais ampla do gênero, ocorrendo na maioria dos estados brasileiros. Habita preferencialmente campos rupestres da Serra do Espinhaço, Serra Dourada e Chapada dos Veadeiros, em altitudes que variam de 400$1800 \mathrm{~m}$, estendendo-se pelos cerrados e regiões mistas de caatinga. No sul da Bahia, é encontrada também em bordas de matas e campos de restinga. Ao norte do Pará, ocorre nas serras dos Carajás e do Ererê e, também, na região dos campos do Ariramba, próximos do rio Trombetas. Ao sul, o limite da espécie coincide com as últimas manchas de cerrado encontradas no Paraná. Em geral, P. mediterranea habita locais com solos arenosos, latossolo vermelho-amarelo e afloramentos rochosos de arenitos e quartzitos e, também, canga de ferro, na Serra dos Carajás (PA). Os períodos de floração e frutificação variam conforme sua área de ocorrência, encontrando-se flores e frutos de janeiro a maio, em Minas Gerais e Goiás / Distrito Federal, e de julho a novembro, na Bahia.

Material selecionado: BRASIL: BAHIA: Barreiras, drenagem do rio Corrente, próximo ao rio Piau, 14/4/1966 (fl., fr.), H.S. Irwin et al. 14820 (F,
MO, NY, RB, UB); Ilhéus, rodovia Canavieiras-Una,

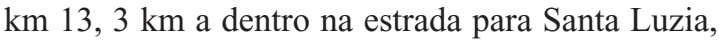
8/10/1990 (fl.), L.T. Silveira et al. s.n. (UEC 24196); Santa Cruz de Cabrália, 1969 (fr.), J.A. de Jesus 495 (RB); Ceará: Crato, Chapada do Araripe, 20/8/1948 (fl., fr.), A.P. Duarte 1416 (RB); Distrito Federal: Brasília, 15/5/1966 (fl., fr.), D.R. Hunt \& J.I. Ramos 5485 (SP, UB); Goiás: Corumbá de Goiás, Serra dos Pireneus, 15 km N de Corumbá de Goiás, estrada para Niquelândia, 17/1/1968 (fl., fr.), H.S. Irwin et al. 18712 (MO, NY, RB, UB); idem, Serra dos Pireneus, 20 km NW de Corumbá de Goiás, próximo da estrada para Niquelândia, 1400 m alt., 27/1/1968 (fl.), H.S. Irwin et al. 19295 (GH, MG, MO, NY, RB, UB); Pirenópolis, Serra dos Pireneus, 20 km E de Pirenópolis, 1000 m alt., 14/1/1972 (fl., fr.), H.S. Irwin et al. 34024 (NY, RB); Serra Dourada, 1969 (fl.), A. Rizzo 4158 (RB); Maranhão: Balsas, 18/9/1979 (fr.), L. Coradin et al. 2205 (CEN); Mato Grosso: Rio Brilhante, rodovia Presidente Prudente - Campo Grande km 340, 9/6/1976 (fl.), H.F. Leitão Filho et al. 2105 (UEC); Minas Gerais: Barão de Cocais, Serra do Caraça, caminho para a Cachoeira, 14/3/1990 (fl., fr.), L.T. Silveira et al. s.n. (UEC 24192); Belo Horizonte, Pico do Itabirito, 50 km SE de Belo Horizonte, 1750 m alt., 2/2/1968 (fl.), H.S. Irwin et al. 19866 (NY, UB); Diamantina, Neco Mota, 4/11/1937 (fl.), H.M. Barreto 9431 (SP); idem, 10 km SW de Diamantina, 22/1/1969 (fl., fr.), H. S. Irwin et al. 22442 (F, GH, MO, NY, RB, UB); PARÁ: Marabá, Serra dos Carajás, N-4, 700-750 m alt., 4/3/1984 (fr.), A.S.L. da Silva et al. 1769 (INPA); idem, Serra dos Carajás, estrada para o campo N-1, 2/4/1977 (fl., fr.), M.G. Silva \& R. Bahia 2997 (NY); idem, Serra dos Carajás, Serra Norte, N-1, 18/4/1970 (fl.), P. Cavalcante \& M. Silva 2636 (UB, UEC); Oriximiná, campos do Ariramba, 25/1/1909 (fl., fr.), A. Ducke s.n. (RB 11388); idem, campos do Ariramba, rio Trombetas, 9/12/1910 (fl.), A. Ducke s.n. (BM, RB 11937); ParanÁ: Carambeí, rio São João, 17/12/1965 (fl., fr.), R. Reitz \& R.M. Klein 17864 (B, F, NY); Pernambuco: Betania, Serra dos Arrombados, 24/5/1971 (fl., fr.), E.P. Heringer et al. 877 (IPA, RB, UB); Piauí: Santa Filomena, 81 km SE de Santa Filomena, na estrada para Gilbues, 21/ 5/1991 (fl.), J.M. Valls et al. 13051 (CEN); RIO DE Janeiro: Petrópolis, Araras, 25/2/1974 (fl.), G. Martinelli 219 (RB); SÃo PAULO: Itararé, 17/1/1987 (fl., fr.), A. Krapovickas \& C.L. Cristóbal 40941 (A, 
$\mathrm{K}$ ); Tocantins: Santo Antonio, alto rio Tocantins, 24/4/1933 (st.), B.A. Krukoff 2081 (A, G, K).

Periandra gracilis Irwin \& Arroyo, Brittonia 24:327. 1972. Tipo: Brasil, Distrito Federal, Córrego Alogado, Parque Municipal do Gama, ca. 20 km SW de Brasília, "slender shrub ca. $1 \mathrm{~m}$ tall. Corolla purple within, paler without. Fruit green. Cerrado and wooded talus", 18 mar. 1966, H.S. Irwin et al. 14064 (holótipo NY, isótipos K, MO, P, RB!, SP!, UB!, US.; fotografia do holótipo $\mathrm{K}$ !).

Figuras 27-36.

Arbustos eretos, até 1,5 m alt. Partes vegetativas glabras ou com indumento pubérulo. Folhas com estípulas 3-5 x 1-2 mm compr., ovado-lanceoladas; pecíolos 2-12 mm compr.; ráquis foliar 5-17 mm compr.; estipelas 3-4 mm compr.; peciólulos 1-2 mm compr.; folíolos 5,3-12,5 x 1,6-4,5 cm, lanceolados, elípticos ou oblongos, base aguda ou obtusa, ápice agudo ou obtuso, cartáceos ou coriáceos, discolores, face abaxial pruinosa com nervuras pubérulas, face adaxial glabra, com nervura central pubérula. Inflorescência axilar e terminal, pauciflora, até 8 flores, laxa, pedúnculo 4-10 cm compr., anguloso; brácteas 2-3 x 1-2 mm, ovadas. Flores 2,5-3 cm compr.; pedicelos 7-10 mm compr.; bractéolas 3-4,5 x 1,5-2,5 mm, ovadas; tubo calicino 3,5 mm compr.; lacínias do lábio carenal triangulares, 3-5 mm compr.; vexilo 2,2-2,6 x 2,2-2,9 cm, externamente pubérulo e internamente com tricomas escamiformes; alas 2,1-2,3 cm compr., pubérulas externamente; pétalas da carena 2,2 cm compr., externamente pubérulas; estames $1,8 \mathrm{~cm}$ compr.; ovário 1,3 cm compr., pubescente; estilete $8 \mathrm{~mm}$ compr., glabro. Legume 6-12 cm compr., castanho, pubérulo; sementes até 14 por fruto, $6,5 \times 4 \mathrm{~mm}$, oblongas; testa castanho-avermelhada, lisa; hilo oblongo.

Comentários: Irwin \& Arroyo (1972) sugerem que $P$. gracilis tenha origem híbrida a partir de $P$. mediterranea e $P$. heterophylla, considerando a morfologia dos folíolos e inflorescências e suas distribuições. P. gracilis é identificada por suas inflorescências laxas, com até 8 flores e pedúnculo de $4-10 \mathrm{~cm}$ compr., o que a diferencia de $P$. mediterranea, espécie mais próxima. . gracilis foi descrita como endêmica dos cerrados de Brasília, DF, mas há registros em Goiás e Mato Grosso do Sul. Habita o cerrado e matas de galeria, estando associada geralmente a ambientes próximos de cursos d'água e apresenta flores e frutos nos meses de janeiro a julho.
Material selecionado: BRASIL: Distrito FedERAL: Brasília, Bacia do rio São Bartolomeu, 4/1/1980 (fl., fr.), E.P. Heringer et al. 3039 (MG, MO); idem, Bacia do rio São Bartolomeu, 3/5/1980 (fl., fr.), E.P. Heringer 4227 (MO); idem, Parque Municipal do Gama, 45 km S de Brasília, 950 m alt., 12/7/1976 (fl., fr.), P.H. Davis 60121 (UEC); GoiÁs: Alexania, $1,5 \mathrm{~km} \mathrm{~W}$ do rio Areias, ao longo da rodovia BR-60, L de Alexania, $16^{\circ} 7^{\prime}$ 'S e $4^{\circ} 22^{\prime} \mathrm{W}, 13 / 3 / 1985$ (fl.), J.F.M. Valls et al. 8280 (CEN); MATo Grosso do SuL: sem localidade, estrada de Três Lagoas, 29/1/1979 (fl.), E.P. Heringer et al. 963 (NY).

Periandra pujalu Emmerich \& Senna, Bol. Mus. Nac. n.s. Botânica 57:1. 1980. Tipo: Brasil, Mato Grosso, Parque Indígena do Xingu, Posto Leonardo, “em beira de mata e cerrado", 21/6/1979 (fl.), M. Emmerich 4669 \& L. Senna 40 (holótipo R!; isótipo RB!).

Figuras 37-47.

Trepadeiras volúveis, 2(-8)m alt., estoloníferas. Partes vegetativas esparso a densamente pubérulas, às vezes pubérulas e seríceas. Folhas com estípulas 2-3 x 1,5-2 mm; pecíolos 10-35(-80) mm compr.; ráquis foliar 4-13(-22) $\mathrm{mm}$ compr.; estipelas 2-3 mm compr.; peciólulos 2-4 mm compr.; folíolos 4-12,5 x 2-6,8 cm, ovados ou ovado-lanceolados, base cordada, subcordada ou arredondada, ápice acuminado ou agudo, submucronado, cartáceos ou coriáceos, face abaxial com nervuras levemente pubérulas ou glabrescentes, pruinosa nos espaços entre os retículos, face adaxial glabra com a nervura central pubérula ou glabrescente. Inflorescência axilar, pauciflora, pedúnculo 5-22 mm compr.; brácteas 2-3 x 1,5-2 mm, ovadas. Flores 2,8-3,2 cm compr.; pedicelos 5-9 mm compr.; bractéolas 3-5 x 2,5-4 mm, ovadas ou suborbiculadas, agudas; tubo calicino $3-5 \mathrm{~mm}$ compr.; lacínias do lábio carenal triangulares, 3-5 mm compr.; vexilo 2,4-3,1 x 2,8-3,8 cm; alas 2,5 cm compr.; pétalas da carena 2,6 cm compr.; estames 2,8-3,4 cm compr.; ovário 1,4 cm compr., piloso; estilete 1,2 cm compr., piloso até abaixo da metade. Legume 10,6$13,5 \mathrm{~cm}$ compr., castanho; sementes 11-12 por fruto, 6-7 x 4-4,5 mm, oblongas; testa castanha, lisa; hilo oblongo.

Comentários: P. pujalu se aproxima de P. mediterranea e $P$. gracilis, tendo em comum a morfologia floral, porém diferencia-se de ambas pelo hábito volúvel. Em relação a $P$. densiflora, $P$. pujalu é prontamente identificada pela forma e tamanho das lací- 


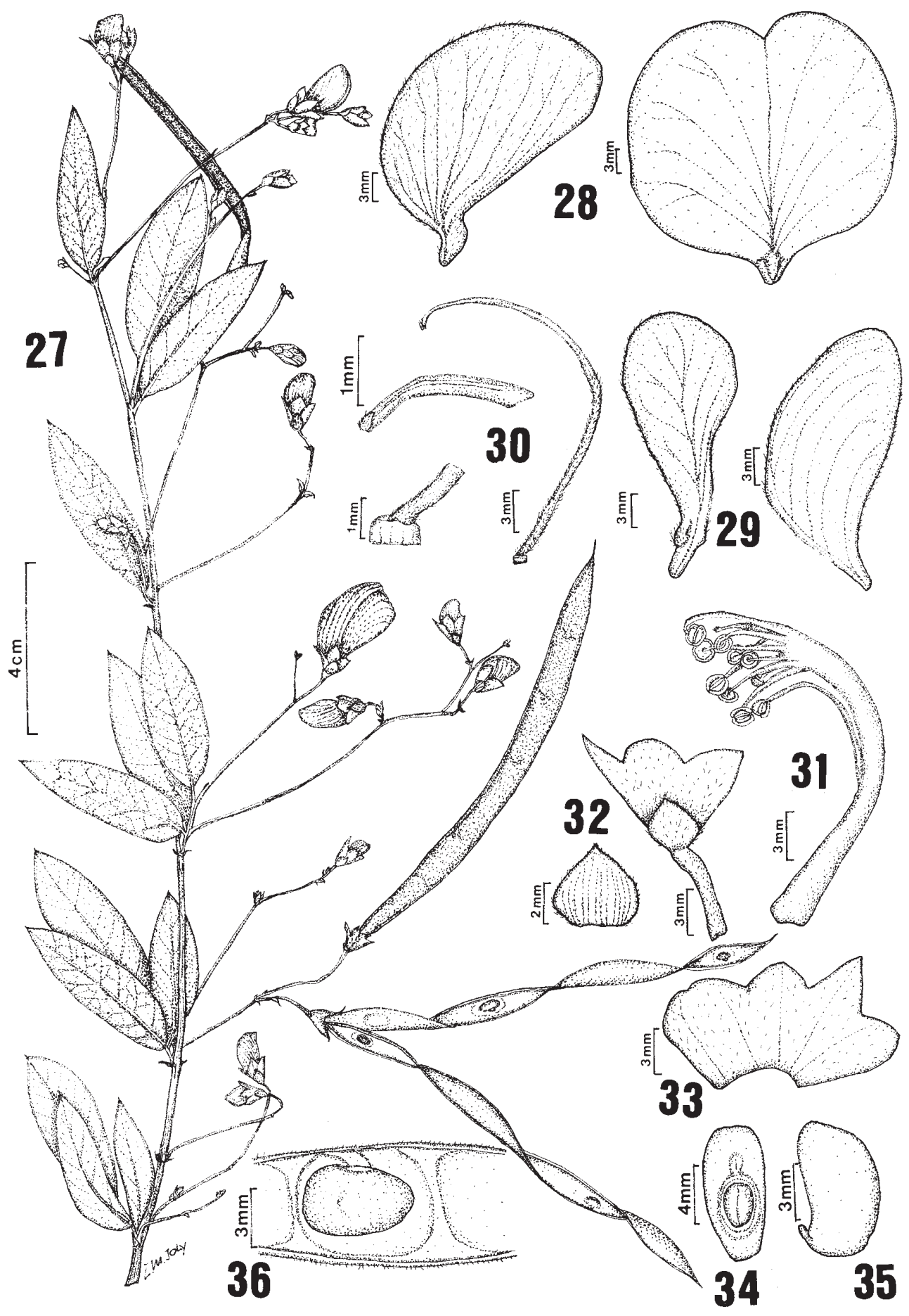

Figuras 27-36. P. gracilis Irwin \& Arroyo (Heringer 4227). 27. Aspecto do ramo; 28. Vexilo, vista lateral e face ventral; 29. Ala e carena; 30. Gineceu, ápice do estilete e estigma, e disco nectarífero basal; 31. Androceu; 32. Cálice e bractéola; 33. Cálice; 34. Semente em vista lateral (Davis 60121B); 35. Embrião (Davis 60121B); 36. Semente no fruto (Davis 60121B). 


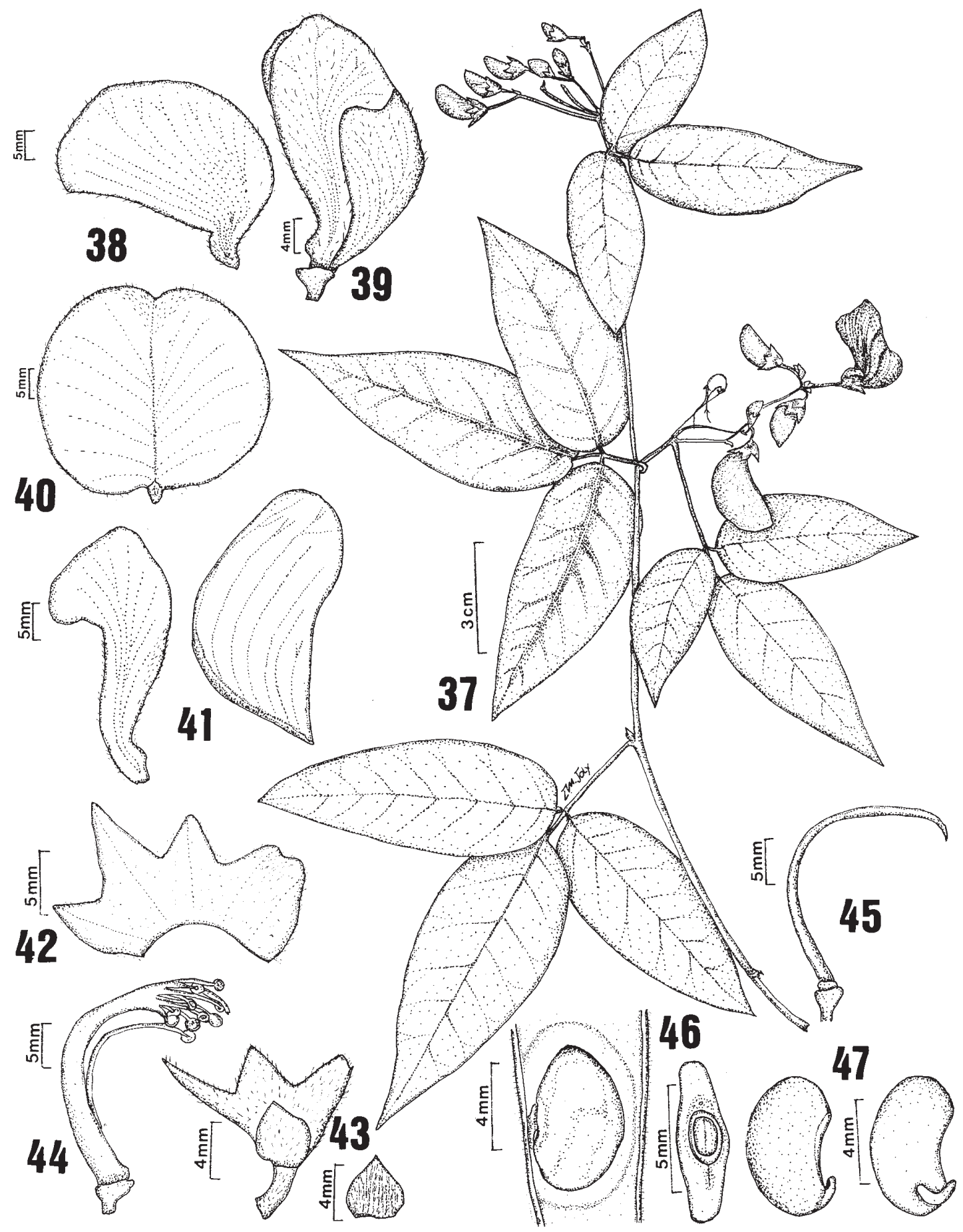

Figuras 37-47. P. pujalu Emmerich \& Senna (Santos 1754). 37. Aspecto do ramo; 38. Vexilo, vista lateral; 39. Ala e carena; 40. Vexilo, face ventral; 41. Ala e carena, face ventral; 42. Cálice; 43. Cálice e bractéola; 44. Androceu e gineceu; 45. Gineceu; 46. Semente no fruto e em vista lateral (Coradin 7279); 47. Embrião (Coradin 7279). 
nias do cálice (triangulares, com 2-5 mm compr.) e bractéolas também mais curtas (3-5 x 2,5-4 mm). Esta espécie foi descrita a partir de coletas no Mato Grosso, onde está mais amplamente distribuída, ocorrendo em cerrado, em latossolo vermelho-amarelo com texturas argilosa ou areno-argilosa, e em mata de galeria, em solo de várzea, entre 250-500 m de altitude. Neste estudo, P. pujalu teve ampliada sua área de distribuição que passa a incluir Bahia e Minas Gerais, onde é encontrada em campo rupestre e mata de encosta. Os períodos de floração e frutificação de P. pujalu se estendem de abril a setembro.

Material selecionado: BRASIL: BAHIA: Lençóis, Serra de Lençóis, ca. 4 km NE de Lençóis pela estrada velha, $41^{\circ} 22^{\prime} \mathrm{W}$ e $12^{\circ} 32^{\prime}$ 'S, 23/5/1980 (fl.), R.M. Harley et al. 22450 (K); Mato Grosso: Diamantino, 28/8/1984 (fr.), L. Coradin et al. 7044 (CEN); Luciara, 4,8 km L do rio Xingu, em direção a São José do Xingu na BR-080, 13/6/1990 (fl.), J.M. Valls et al. 12561 (CEN); São Félix do Araguaia, 15/9/1984 (fr.), L. Coradin et al. 7279 (CEN); Xavantina, rio Suaizinha, 290 km N de Xavantina, 12/6/1968 (fl.), R.R. de Santos \& R. Souza 1754 (K); Minas Gerais: Montes Claros, estrada para Francisco Sá, km 20, 24/5/1978 (fl.), H.F. Leitão Filho et al. 7875 (UEC).

Periandra densiflora Benth., Comm. Leg. Gen. p.58. 1837. Tipo: Brasil, Minas Gerais, Ouro Fino, 1837 (fl.), Pohl s.n. (holótipo K!, fotografias A!, F!, NY!, UEC!).

Figuras 48-58.

Glycinopsis densiflora (Benth.) Kuntze, Rev. Gen. Plant. 1:190. 1891.

Trepadeiras volúveis, até $3 \mathrm{~m}$. Partes vegetativas pubérulas ou pubérulas e seríceas a subvelutinas. Folhas com estípulas 2-5 x 1,5-2 mm, ovadolanceoladas; pecíolos 3-27 mm compr., raramente sulcados; ráquis foliar 4-23 mm compr.; estipelas 2$3 \mathrm{~mm}$ compr., peciólulos 1-2,5 mm compr.; folíolos 2,6-5,3 x 1,9-3,5 cm, ovados, ovado-oblongos ou suborbiculados, base arredondada ou subcordada, ápice obtuso, agudo ou arredondado, às vezes levemente emarginado, cartáceos, discolores, face abaxial pruinosa e pubérula, com nervuras pubérulas e ligeiramente pilosas, face adaxial pubérula ou glabra. Inflorescências axilares, paucifloras, até 3 flores, pedúnculo quase nulo ou, ocasionalmente $1,5-10 \mathrm{~cm}$ compr.; brácteas 3-5 × $2 \mathrm{~mm}$, ovado-lanceoladas. Flores 3,5-4,2 cm compr.; pedicelo 8-12 mm compr.; bractéolas 4-10 x 3-6 mm, ovado-lanceoladas; tubo calicino $5 \mathrm{~mm}$ compr.; lacínia mediana do lábio carenal lanceolada, 9-14 mm compr., as demais subtriangulares, 3-5 mm compr.; vexilo 3,5-3, 8 x 3,5$3,6 \mathrm{~cm}$, piloso externamente; alas $3-3,2 \mathrm{~cm}$ compr.; peças da carena 2,5-2,7 cm compr.; estames $3,5 \mathrm{~cm}$ compr.; ovário 2,1 cm compr., seríceo; estilete 1,2 cm compr., plano ou anguloso, piloso até abaixo da metade. Legume 10-12 cm compr.; sementes 8-11 por fruto, 4,5-5 x 3-4 mm, oblongas, testa castanha, com manchas negras.

Comentários: Verificou-se a ocorrência simpátrica de $P$. densiflora e $P$. pujalu em várias localidades como Xavantina (Mato Grosso) e Montes Claros (Minas Gerais). As espécies apresentam grande similaridade floral e sobreposição nos respectivos períodos de floração. Possivelmente, o mecanismo de isolamento reprodutivo existente entre $P$. densiflora e $P$. pujalu atue na interação pólen-estigma, visto serem os grãos de pólen destas espécies bastante diversos morfologicamente. P. densiflora é a única espécie do gênero que apresenta grãos heterocolpados (Funch \& Watanabe 1994). P. densiflora é identificada pelo hábito volúvel, o lábio carenal do cálice com lacínias ovadas, sendo a mediana lanceolada, mais longa que as demais (9-14 $\mathrm{mm}$ compr.), e bractéolas mais longas que o tubo calicino (4-10 mm compr.). É encontrada em Goiás, Minas Gerais, Mato Grosso, Pará, São Paulo e Distrito Federal. A maior parte das coleções é oriunda de Minas Gerais, ocorrendo em campos e cerrados, a 400-1200 m de altitude. No Pará, ocorre na região dos "Campos do Ariramba", com vegetação de campo e campinarana. Os períodos de floração e frutificação de $P$. densiflora se estendem de março a setembro.

Material selecionado: BRASIL: Distrito FEDERAL: Brasília, Bacia do Rio São Bartolomeu, 22/4/1980 (fl., fr.), E.P. Heringer et al. 4461 (NY); Goí́s: Formoso, SE de Serra Dourada, 20 km E de Formoso, 15/5/1956 (fl.), E.Y. Dawson 14816 (NY); Minas Gerais: Belo Horizonte, Vila Paraíso, 27/7/ 1933 (fl., fr.), H.M. Barreto 5574 (SP); Mato GrosSo: São Félix do Araguaia, 15/9/1984 (fr.), L. Coradin et al. 7300 (CEN); Xavantina, Vale dos Sonhos, $14^{\circ} 38^{\prime}$ 'S e $52^{\circ} 14^{\prime}$ W, 2/4/1968 (fl., fr.), D. Philcox \& B. Freeman 4705 (K, NY, RB, UB); PARÁ: Oriximiná, região dos campos do Ariramba, 5/7/1912 (st.), A. Ducke s.n. (MG 11909). 


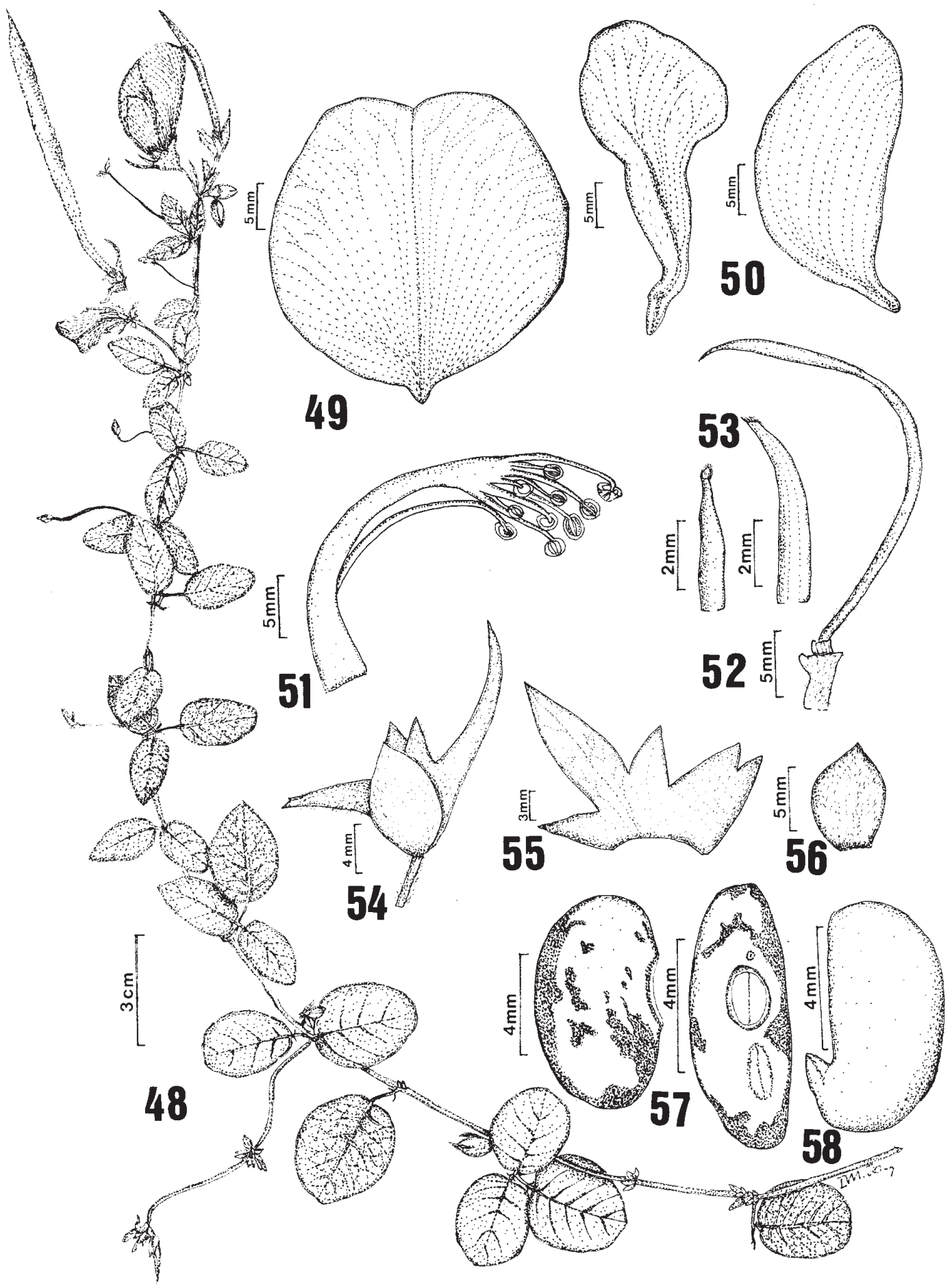

Figuras 48-58. P. densiflora Benth. (Dawson 14816). 48. Aspecto do ramo; 49.Vexilo; 50. Ala e carena; 51. Androceu; 52. Gineceu; 53. Ápice do estilete e estigma, em vistas frontal e lateral; 54. Cálice e bractéola; 55. Cálice; 56. Bractéola; 57. Semente em vistas frontal e lateral (Coradin 7300); 58. Embrião (Coradin 7300). 
Periandra subg. Coccinea Funch \& Barroso subg. nov.

Espécie-tipo: Periandra coccinea (Schrad.) Benth.

Herbae vel sufrutices volubiles vel erecti; ramulis et foliis pillis canescenti-ochraceis puberulis ac pilosis vel subvelutinis; pedunculis axillaribus, 13-flori, cimosi, 4,5-27 cm lg.; flores coccinei; allis oblongis vel sigmoideo angustato-obtusis; granula pollinis grandia, suboblata, tripora, rugulata; per germinationem faneroepigaeae.

Ervas ou subarbustos escandentes ou eretos, ascendentes, até $3 \mathrm{~m}$; indumento pubérulo e seríceo a subvelutino, canescente-ocráceo, recobrindo as partes vegetativas; inflorescências cimosas, axilares, pedúnculo 4,5-27 cm de compr.; corola vermelha; alas estreitas, oblongas ou sigmóides, com ápice obtuso; grãos de pólen grandes, suboblatos, 3porados, rugulados; plântulas faneroepígeas.

Periandra coccinea (Schrad.) Benth., Comm. Leg. Gen. p.57. 1837.

Figuras 59-71.

Clitoria coccinea Schrad., Goett. Gel. Anz. 1:717. 1821. Tipo. Brasil, Bahia.

Periandra acutifolia Benth., Comm. Leg. Gen. p.57. 1837. Tipo: Brasil, Bahia, "Corallino", Pohl s.n. (lectótipo K!, aqui designado; fotografias A!, NY!, UEC!); “Coxeiro", Martius s.n. (não localizado).

Glycinopsis coccinea (Schrad.) Kuntze, Rev. Gen. Plant. 1:190. 1891.

Glycinopsis acutifolia (Benth.) Kuntze, Rev. Gen. Plant. 1:190. 1891.

Trepadeiras volúveis, até $3 \mathrm{~m}$, ocasionalmente arbustos flexuosos, estoloníferas. Partes vegetativas pubérulas e seríceas a velutinas. Folhas com estípulas 4-9 x 1,5-4 mm, vináceas; pecíolos 10-65 mm compr.; ráquis foliar 4-25 mm compr.; estipelas 3-6 mm compr.; peciólulos 2-6 mm compr.; folíolos 3,811,6 x 2,4-6,4 cm, ovados, ovado-oblongos, oblongos, elípticos ou suborbiculados, base arredondada ou obtusa, ápice acuminado ou agudo, às vezes arredondado, cartáceos, membranáceos ou coriáceos, rugosos ou subulados, face abaxial pruinosa, pubérula e serícea a subvelutina, com nervuras pubérulas e seríceas ou subvelutinas, face adaxial ligeiramente serícea, ou pubérula e serícea, canescente, com a nervura central serícea ou pubérula e serícea. Inflorescências cimosas, axilares, paucifloras com 3-4 flores (cicatrizes de até 8 flores), pedúnculos 4,5-24,5 cm compr., estriados; brácteas 4-9 x 1,5-3 mm, ovadas a lanceoladas, acuminadas. Flores 3,3-4,6 cm compr.; pedicelos 6-20 mm compr.; bractéolas 8-9 x 2-4 mm, ovado-lanceoladas ou lanceoladas, acuminadas; tubo calicino 3-4 mm compr., pubérulo ou seríceo, lábio carenal com lacínias triangulares, lacínia mediana 5-8 mm compr. e as demais 3-5 mm compr.; vexilo 3,2-4,5 x 2,9-4 cm; alas 2,7-3,6 cm compr.; pétalas da carena 2,6-3,6 cm compr.; estames 3,2-4,1 cm compr. Ovário $8-19 \mathrm{~mm}$ compr., piloso; estilete $22 \mathrm{~mm}$ compr., glabro ou pubescente; estigma piloso. Legume 11,5$14,5 \mathrm{~cm}$ compr., castanho; sementes $12-14$ por fruto, 4,5-5,5 x 3-3,5 cm, reniformes; testa cinza ou castanha com manchas negras; hilo oblongo.

Comentários: Schrader (1821), ao descrever Clitoria coccinea, comentou seu parentesco com C. falcata Lam. De Candolle (1825) sinonimizou esta espécie com C. coccinea, possivelmente considerando a opinião de Ness von Esenbeck (1821) que sugeria este procedimento. No entanto, examinou-se a descrição de Lamark (1786), confirmando que $C$. falcata exibe caracteres bastante diversos (pétalas azuladas ou púrpuras, cálice oblongo, frutos curvos, falcados, sementes brancas com a região do hilo vermelha) e distribuição na Ilha de São Domingos - Hispaniola, retirando-a da sinonímia de $P$. coccinea. Bentham (1837) descreveu $P$. acutifolia com características muito semelhantes àquelas encontradas em $P$. coccinea. Na Flora brasiliensis, Bentham (1859) manteve P. acutifolia como táxon independente, porém sugeriu que este pudesse constituir uma variedade de $P$. coccinea, diferenciando-se apenas por caracteres de textura e forma foliares. Mattos \& Oliveira (1973) sinonimizaram P. acutifolia coma $P$. coccinea, o que é mantido no presente trabalho. $P$. coccinea é identificada pelas folhas longamente pecioladas (10-65 $\mathrm{mm}$ compr.) e folíolos elípticos ou ovais, caracteres que a separam de $P$. heterophylla, espécie mais próxima. Ocorre na Bahia, Ceará, Goiás, Maranhão, Mato Grosso, Minas Gerais, Pará, Pernambuco, Piauí, Roraima, Tocantins e Distrito Federal. Da Bahia provém a maioria das coletas da espécie. P. coccinea habita campo rupestre e cerrados, sendo freqüente em ambientes perturbados, ao longo de estradas e cami- 


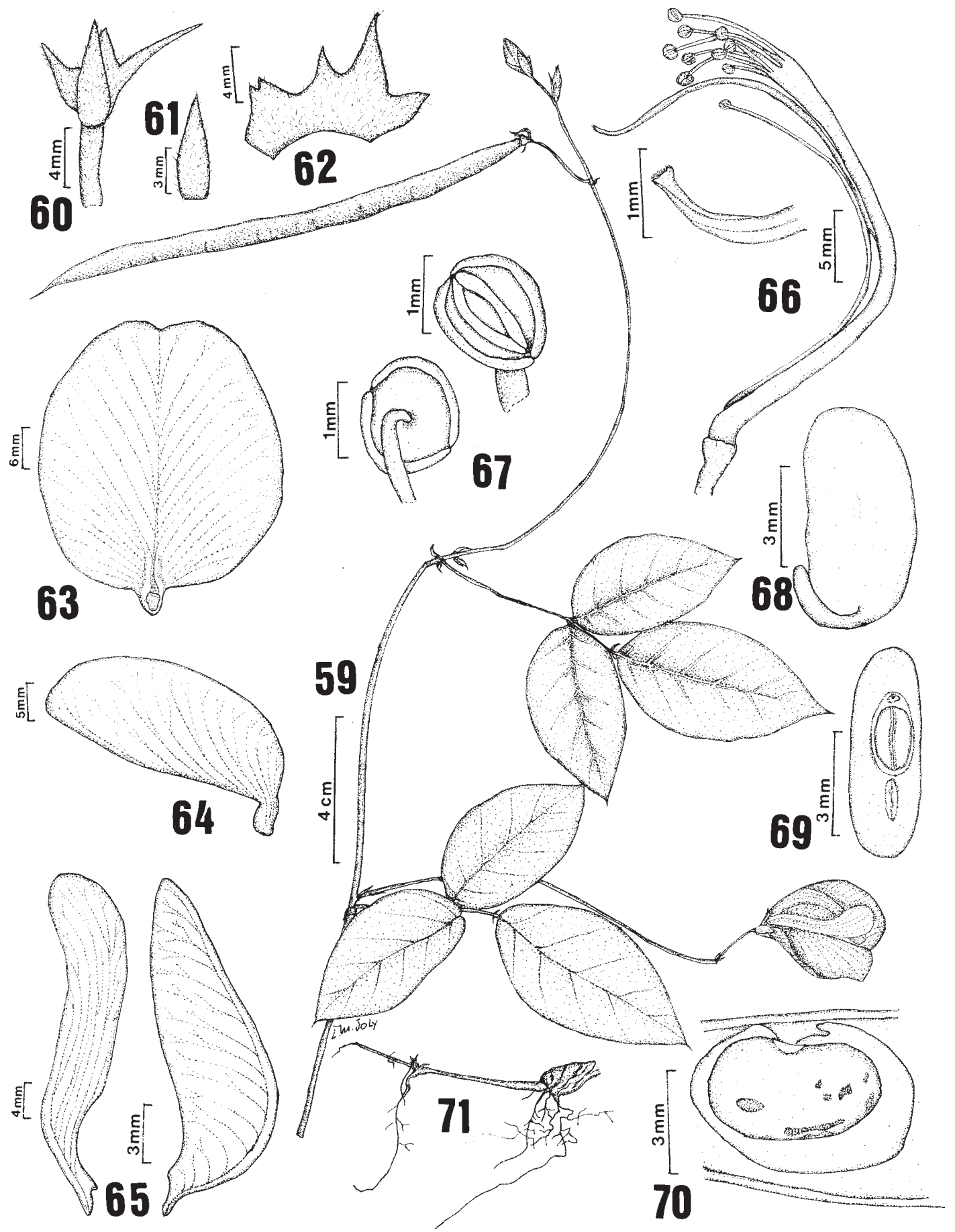

Figuras 59-71. P. coccinea (Schrad.) Benth. (Davidse 12291). 59. Aspecto do ramo, cálice e bractéola; 61. Bractéola; 62. Cálice; 63. Vexilo, face ventral; 64. Vexilo, vista lateral; 65. Ala e carena; 66. Androceu e gineceu, com detalhe do ápice do estilete e estigma; 67. Antera; 68. Embrião (Queiroz 1689); 69. Semente em vista lateral (Queiroz 1689); 70. Semente no fruto (Queiroz 1689); 71. Estolão. 
nhos. Os períodos de floração e frutificação estendem-se de abril a julho.

Material selecionado - BRASIL: BAHIA: Barra do Choça, Serra da Conquista, $7 \mathrm{~km}$ W de Barra do Choça, na estrada para Vitória da Conquista, 30/3/1977 (fl., fr.), R.M. Harley et al. 20196 (MO, NY, RB, U, UEC); Ituaçu, $13^{\circ} 48^{\prime}$ S e $41^{\circ} 16^{\prime} 41^{\prime}$ ' W, 23/6/1987 (fl., fr.), L.P. de Queiroz et al. 1689 (HUEFS); GoiÁs: Anápolis, rodovia Anápolis-Belém BR-153 km 55, 30/8/1978 (fr.), A. Allem et al. 2137 (CEN); Goiania, 47 km S de Goiania, BR-153, 800 $\mathrm{m}$ alt., 10/4/1976 (fl., fr.), G. Davidse et al. 12291 (SP); Maranhão: Codó, 18/7/1910 (fl., fr.), A. Ducke s.n. (MG 613, RB 11935); Mato Grosso: Barra do Garças, estrada Barra do Garças - Xavantina, a $56 \mathrm{~km}$ de Barra do Garças, 21/4/1978 (fl., fr.), G.J. Shepherd et al. 7510 (BM, INPA, UEC); Minas GERAIs: Pedra Azul, $35 \mathrm{~km}$ de Pedra Azul, na estrada para Almenara, 22/6/1980 (fl.), J.M. Valls 5477 (CEN); PARÁ: Marabá, Serra dos Carajás, 6 km SE de ANZA, Campo N1, 6³'S e 50¹6'W, 19/5/1982 (fl., fr.), C.R. Sperling et al. 5772 (F, NY); Pernanbuco: Inajá, Serra Negra, 19/8/1980 (fl., fr.), D. Andrade Lima 25783 (F, IPA); PiAú, Sete Cidades: Parque Nacional de Sete Cidades, Cachoeira do Riachão, 15/9/1977 (fl.), G.M. Barroso \& E.F. Guimarães 203 (RB); Rio DE JANEIRO: Rio de Janeiro, Jardim Botânico do Rio de Janeiro, XII-1928 (fl.), A. Ducke 220 (RB); Tocantins: Porto Nacional, 16/5/1991 (fl.), J.F.M. Valls et al. 12969 (CEN).

Periandra heterophylla Benth., Comm. Leg. Gen. p.57. 1837. Tipo: Brasil, Minas Gerais, Santa Luzia, s.d. (fl.), Pohl s.n. (lectótipo K!; fotografias A!, F!, NY!, UEC!). Brasil, s.l., s.d. (fr.), Schucht s.n. (paralectótipo K!; fotografias A!, F!, NY!, UEC!).

Figuras 72-79.

Glycinopsis heterophylla (Benth.) Kuntze, Rev. Gen. Plant. 1:190. 1891.

Ervas ou subarbustos eretos ou ascendentes, ocasionalmente volúveis, subramificados, até $1,5 \mathrm{~m}$ de alt. Partes vegetativas pubérulas e levemente seríceas a velutinas. Folhas com estípulas 4,5-8 x 2-3 mm, ovado-lanceoladas; pecíolos 2-3 mm compr.; ráquis foliar 1,2-3 cm compr.; estipelas 2-3 mm compr.; peciólulos 2-3 mm compr.; folíolos 3,8-10,3 x 2,5$5,3 \mathrm{~cm}$, ovado-oblongos, base arredondada ou cordada, ápice obtuso, arredondado ou agudo, coriáceos, ligeiramente rugosos a bulados, pubérulos e seríceos, face abaxial com nervuras pubérulas e seríceas a subvelutinas, face adaxial com nervuras pubérulas e seríceas. Inflorescência cimosa, axilar, pauciflora com 3-4 flores, pedúnculo $15-27 \mathrm{~cm}$ compr.; brácteas 4-8 x 1-2 mm, ovado-lanceoladas ou lanceoladas. Flores 3-4,5 cm compr.; pedicelos 7-17 mm compr.; bractéolas 4-9 x 1,5-4 mm, ovadolanceoladas; tubo calicino 3-4 mm compr., pubérulo ou tomentoso, lábio carenal com lacínias triangulares 3-5 mm compr.; vexilo 2,7-4,5 x 2-3,5 cm; alas 2,7-3,5 cm compr., pubérulas ou glabrescentes; pétalas da carena 2,7-3,5 cm compr., pubérulas ou glabrescentes; estames 3,1-3,3 cm compr.; ovário 817 mm compr., seríceo; estilete 3-1,6 cm compr., seríceo até abaixo da metade; estigma glabro. Legume 10,5-15 cm compr., castanho, seríceo a glabrescente ao longo das margens; sementes 1620, 4-6 x 2-3 mm, reniformes; testa castanha com manchas negras; hilo oblongo.

Comentários: P. heterophylla ocorre na Bahia, Goiás, Maranhão, Mato Grosso, Mato Grosso do Sul, Minas Gerais, Piauí, São Paulo, Tocantins e na Província de Santa Cruz (Bolívia). É encontrada em cerrados e campos rupestres, a 400-1000 m de altitude, em solo arenoso ou latossolo vermelho-amarelo. O período de floração e frutificação se estende de agosto a abril.

Material selecionado - BRASIL: BAHIA: Barreiras, $5 \mathrm{~km} \mathrm{~W}$ de Barreiras, área de acesso do rio de Ondas, ao longo da BR-242, 12/6/1981 (fl.), J.M. Valls et al. 6049 (CEN); GoiÁs: Guará, 10 km S de Guará, 18/3/1968 (fl., fr.), H.S. Irwin et al. 21303 (B, F, G, GH, MO, NY, RB, UB); Mato Grosso: Barra do Garças, Serra do Roncador, 24/11/1969 (fl., fr.), G. Eiten \& L.T. Eiten 9514 (SP); sem localidade indicada, Chapada dos Guimarães, salgadeira ramal à direita, 21/3/1983 (fr.), P. Lisboa et al. 3238 (MG); Mato Grosso do Sul: Nossa Senhora do Livramento, 22/10/1985 (fl.), J.M. Valls et al. 9314 (CEN); Maranhão: Estreito, $3 \mathrm{~km} \mathrm{~S}$ de Estreito, rodovia para Carolina, 16/3/1985 (fl., fr.), J.M. Valls et al. 8348 (CEN); Minas Gerais: Belo Horizonte, Parque Vera Cruz, 19/1/1934 (f1., fr.), H.M. Barreto 5700 (SP); Tocantins: Gurupi, $11^{\circ} 44^{\prime} \mathrm{S}$ e $49^{\circ} 4^{\prime} \mathrm{W}$, 26/12/1969 (fl., fr.), G. Eiten \& L. Eiten 10016 (NY, SP). BOLÍVIA: SANTA CRuz: Província Velasco, 2 km SE de San Ignacio, 28/12/1985 (fl.), R. Seidel 16 (NY); sem localidade indicada, 28/10/1985 (fl., fr.), T. Killen 1319 (NY). 


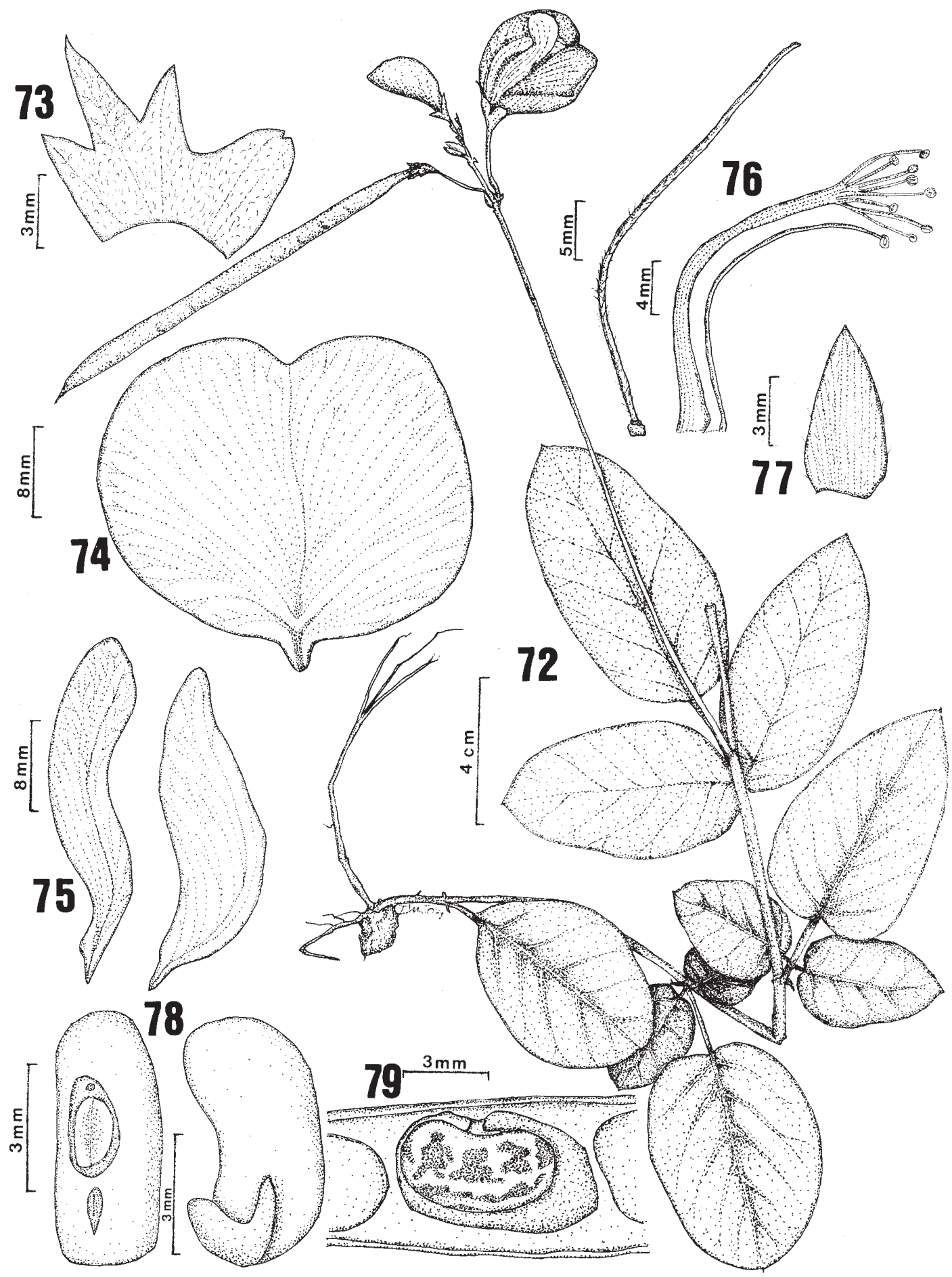

Figuras 72-79. P. heterophylla Benth. (Irwin 21303). 72. Aspecto do ramo; 73. Cálice; 74. Vexilo; 75. Ala e carena; 76. Androceu e gineceu; 77. Bractéola; 78. Semente em vista lateral e embrião (Lisboa 3238); 79. Semente no fruto (Lisboa 3238). 
Espécie duvidosa:

Periandra berteriana (DC.) Benth., Comm. Leg. Gen. p.57. 1837.

Clitoria berteriana DC., Mem. Leg. 4:239. 1825.

De Candolle (1825) descreveu Clitoria berteriana com corola amarela, vexilo com uma depressão glandulosa interna, estames diadelfos sendo o décimo bastante distinto dos demais e estilete dilatado como um cone reverso, encontrada na Ilha de São Domingos - Hispaniola. Bentham (1837) transferiu a espécie para o gênero Periandra, próxima de $P$. acutifolia pela morfologia dos folíolos. Há apenas um exemplar identificado como P. berteriana, do herbário de Genebra, estéril e bastante danificado, insuficiente para se obter uma conclusão a respeito da espécie. Assim, P. berteriana foi tratada como espécie duvidosa, considerando a diagnose de De Candolle (1825) que apresenta características muito diversas daquelas encontradas em espécies do gênero Periandra.

Agradecimentos - Agradecemos ao Prof. Luciano Paganucci de Queiroz pela leitura do texto e sugestões valiosas apresentadas ao trabalho.

\section{Referências bibliográficas}

BAUDET, J.C. 1974. Signification taxonomique des caracters blastogéniques dan la tribu des Papilionaceae-Phaseoleae. Bull. Jard. Bot. Nat. Belg. 44:259-293.

BENTHAM, G. 1837. Commentationes de Leguminosarum Generibus. Sollinger, Vienna.

BENTHAM, G. 1859. Leguminosae. In Flora brasiliensis (C.F.P. Martius, ed.). F. Fleisher, Lipsiae, v.15, p.1-346.

BENTHAM, G. 1865. Leguminosae. In Genera Plantarum (G. Bentham \& J.D. Hooker, eds.) Lovell Reeve \& Co., London, v. 1, p.434-600.

DE CANDOLLE, A.P. 1825. Mémoires sur la famille des Légumineuses. A. Belin, Paris, v.4, p.236-240.

DUKE, J.A. \& POLHILL, R.M. 1981. Seedlings of Leguminosae. In Advances in Legume Systematics (R.M. Polhhil \& P.H. Raven, eds.) Royal Botanic Gardens, Kew, v.2, p.941-949.

EMMERICH, M. \& SENNA, L.M. 1980. Estudos de etnobotânica no Parque Indígena do Xingu.1. Uma Periandra (Leguminosae) nova. Boletim do Museu Nacional do Rio de Janeiro Botânica 57:1-3.

FOSTER, A.S. \& GIFFORD JR., E.M. 1979. Comparative morphology of vascular plants. W.H. Freeman \& Co., San Francisco .
FUNCH, L.S. \& WATANABE, H.M. 1994. Morfologia dos grãos de pólen do gênero Periandra Mart. ex Benth. (Leguminosae, Papilionoideae, Phaseoleae). Revista Brasileira de Botânica 17:105-111.

FANTZ, P.R. 1996. Resegregation of Barbieria from Clitoria (Leguminosae: Phaseoleae: Clitoriinae). Sida 17:55-68.

GREUTER, W., BARRIER, F.R., BURDET, H.M., CHALONER, W.G., DEMOULIN, V., HAWKSWORTH, D.L., JORGENSEN, P.M., NICOLSON, D.H., SILVA, P.C. \& TREHANE, P. 1994. International Code of Botanical Nomenclature. Regnum Vegetabili v.131. Koeltz Scientific Books, Königstein.

HICKEY, L.J. 1973. Classification of the architecture of Dicotyledonous leaves. American Journal of Botany 60:17-33.

HOLMGREN, P.K., HOLMGREN, N.H. \& BARNETT, L.C. (eds.) 1990. Index Herbariorum. Part 1: The Herbaria of the World. Ed. 8. New York Botanical Garden, New York.

HUTCHINSON, J. 1964. The Genera of Flowering Plants (Angiosperms) v. 1. Oxford University Press, Oxford.

IRWIN, H.S. \& ARROYO, M.T.K. 1972. A new species of Periandra (Leguminosae: Lotoideae) from the Planalto of Brasil. Brittonia 24:327-329.

LACKEY, J.A. 1981. Phaseoleae. In Advances in Legume Systematics (R.M. Polhill \& P.H. Raven, eds.) Royal Botanic Gardens, Kew, v.1, p.301-327.

LAMARCK, J.B.A.P.M. 1786. Encyclopédie Methodique. Botanique. 2:51.

MATTOS, N.F. \& OLIVEIRA, F. 1973. O gênero Periandra (Leguminosae). Loefgrenia 59:1-18.

MICHELI, M. 1894. Légumineuses nouvelles - Periandra. Bull. Herb. Boissier 2:444-445.

NEES VON ESENBECK, C.G.D. 1821. Notizen. Reise des Prinzen von Neuwied. Flora oder Botaniche Zeitung 4:329.

RADFORD, A.E.; DICKISON, W.C.; MASSEY, J.R. \& BELL, C.R. 1974. Vascular Plant Systematics. Harper \& Row, New York.

RIZZINI, C.T. 1977. Sistematização terminológica da folha. Rodriguesia 29:103-125.

SCHRADER, H.A. 1821. Stück. Goettingifche gelehrte Anzeigen $1: 717$.

SILVEIRA, L.T. 1991. Revisão taxonômica do gênero Periandra Mart. ex Benth. (Leguminosae, Papilionoideae, Phaseoleae). Dissertação de mestrado. Universidade Estadual de Campinas, Campinas.

STANDLEY, P.C. \& STEYERMARK, J.A. 1946. Leguminosae. In Flora of Guatemala (P.C. Standley \& J.A. Steyermark, eds.). Fieldiana: Botany 24:1-368.

STIRTON, C.H. 1981. Petal sculpturing in papilionoid legumes. In Advances in Legume Systematics (R.M. Polhill \& P.H. Raven, eds.) Royal Botanic Gardens, Kew, v.2, p.771-788.

TAUBERT, P.H.W. 1894. Leguminosae. In Die natürlichen Pflanzenfamilien (A. Engler \& K. Prantl, eds.) Wilhelm Engelmann, Leipzig 3:70-388.

TUCKER, S.C. 1987. Pseudoracemes in papilionoid legumes: their nature, development, and variation. Botanical Journal of the Linnean Society 95:181-206. 